\title{
TABLE TENNIS MOVEMENT AMONG OFFICIALS AND EMPLOYEES AT SAIGON UNIVERSITY, VIETNAM
}

\author{
Nguyen Thi Hoang Anh ${ }^{i}$ \\ Faculty of National Defense Education \\ and Physical Education, \\ Saigon University, \\ Vietnam
}

\begin{abstract}
:
Research using the method of synthesis, document analysis and interview has identified six criteria through which the evaluation application provides accurate and comprehensive information about the table tennis movements among officials and employees at Saigon University. In addition, the article also provided information on the form, organization method, time, number of training sessions, time and location, training costs of officials, employees, lecturers and table tennis coaches. The research results are a reference for managers, contributing to the development of the sport movement among officials and employees at Saigon University.
\end{abstract}

Keywords: table tennis movement; officials and employees at Saigon University

\section{Introduction}

Saigon University has 42 affiliated units including Departments, Departments, Middle Schools, Faculty; with a total of about 847 officials and employees (Female: 450, Male: 397). In recent years, Saigon University has been evaluated as one of the universities with a well-developed physical training and sports movement and achieved some remarkable results in the Education and Training block in Ho Chi Minh City. Besides, every year on the occasion of celebrating major national holidays (April 30 - May 1) and Vietnamese Teachers' Day Celebration November 20, the school organizes Sports Festivals for officials and employees and also attracts many officials and employees to participate. In addition, established and trained the team to participate in exchange competitions with schools; Sports festival of universities, colleges and educational units of Education and Training (Trade Union Award); Trade Union Sports Festival for Emulation Division 1, Sports Festival for Emulation Block 24, Self - Defense Cluster 7 Sport Festival, etc.. Through sports activities has contributed to improving health, building a healthy

${ }^{i}$ Correspondence: email nguyenanh20383@gmail.com 
lifestyle, and improving the cultural and spiritual life for officials and employees. However, the number of participating officials and employees is still not significant compared to the total number of officials and employees in the school, in addition, it is also necessary to improve professional qualifications to improve technical and development factors the table tennis movement further. With the above importance, I chose the research direction with the article "Table tennis movement among officials and employees at Saigon University".

The purpose of the article is to provide information about the table tennis movement among officials and employees at Saigon University. This is the basis for proposing solutions to develop the table tennis movement among officials and employees at Saigon University.

In the process, the research team used the following methods: Synthesis Method and documents analysis; Methods of interview and discussion; Full-Statistical methods.

The research work was carried out for 2 years with a group of subjects to survey evaluation criteria and solutions: 12 experts and school sports managers at Saigon University were selected according to the technique judgmental and convenience sample selection.

\section{Research Results}

\subsection{Determining criteria for assessing the current status of physical training and sports movements among officials and employees at Saigon University}

The project proceeds in 2 steps:

Step 1. Statistical evaluation criteria of physical training and sports movements from documents, documents and research works of domestic and foreign authors such as Circular No. 02/2009/TT-BVHTTDL; Circular No. 08/2012/TT-BVHTTDL; Law on Physical Training and Sports, 2018; Circular No. 01/2019/TT-BVHTTDL; based on research purposes, object characteristics and practical conditions at Sai Gon University; The topic selects 06 criteria to assess the current situation of table tennis movement among officials and employees at Saigon University.

Step 2. Interview experts, managers, and physical education instructors. The process of developing a questionnaire and interviewing 12 experts twice a month, with the same assessment method, the same audience and the same content system, the answer is 'agree' and 'disagree'. As a result, we selected the criteria to evaluate the actual situation of the Table tennis movement among officials and employees at Saigon University, which are the criteria with the total number of votes agreeing from $75.00 \%$ of the respondents. Both interviews include 06 criteria with evaluation content:

Criterion 1: Number of officials and employees who regularly practice table tennis.

Evaluation content: Officials and employees who practice table tennis regularly are those who practice at least 2 times a week; each workout for at least 30 minutes; Criteria for the number of officials and employees who regularly practice table tennis is 
determined by the percentage (\%) of the total number officials and employees who regularly practice table tennis compared to the total number of officials and employees in the school.

Criterion 2: Number of table tennis units.

Evaluation content: A table tennis unit is a unit with a number of officials and employees who regularly practice table tennis and can establish a table tennis team with at least 2 people if the unit has from 6 or fewer employees and at least 3 people if the unit has 7 employees - employees more. Units with less than 6 employees, if there are employees, regularly practice table tennis are table tennis units; The criteria for the number of table tennis units is determined as a percentage (\%) of the total number of table tennis units compared to the total number of units in the school.

Criterion 3: Number of table tennis coaches and collaborators.

Evaluation content: Number of table tennis coaches and collaborators who are qualified sports professionals who perform the task of mobilizing, organizing, and guiding people to practice table tennis, perform, competing in the development of table tennis movement in the school; The criterion for the number of table tennis coaches and collaborators is determined by the percentage (\%) of the total number of table tennis coaches and collaborators compared to the total number of coaches and sports collaborators in the school.

Criterion 4: Number of clubs, groups, and teams of table tennis.

Evaluation content: Clubs, groups, and teams of table tennis are established and recognized according to the regulations of the school, with the function of propagating and mobilize employees with similar interests to organize and disseminate, guide training and table tennis competitions in order to satisfy the needs of physical training, entertainment, health promotion and life improvement. Cultural and spiritual life and improvement of table tennis achievements for officials and employees in the school; Criteria for the number of table tennis clubs, groups, and teams is determined by the total number of table tennis clubs in the school.

Criterion 5: Table tennis training and competition facilities.

Evaluation content: Total number of table tennis training and competition facilities including: Total number of table tennis training and competition facilities; the criterion for the number of table tennis practice and competition works is determined by the total number of table tennis practice and competition houses in the school.

Criterion 6: Number of table tennis tournaments held annually at the school.

Evaluation content: Criteria for the number of table tennis tournaments held annually is determined by the total number of table tennis tournaments held in the school. 


\subsection{Evaluate the current situation of table tennis movement among officials and employees at Saigon University}

The topic assesses the current situation of physical training and sports movements among officials and employees at Saigon University through 6 criteria identified in Section 1, specifically as follows:

To evaluate criteria No. 1 and No. 2, the study conducted a survey of 361 officers and employees of Saigon University according to each unit, the results are presented in Table 2.1.

Table 2.1: Statistics of Saigon University's officers and employees participating in regular table tennis practice

\begin{tabular}{|c|c|c|c|c|c|c|}
\hline \multirow{2}{*}{ Ordinal } & \multirow{2}{*}{ Unit } & \multicolumn{3}{|c|}{$\begin{array}{c}\text { Practice table } \\
\text { tennis regularly }\end{array}$} & \multicolumn{2}{|c|}{$\begin{array}{c}\text { Table tennis } \\
\text { unit }\end{array}$} \\
\hline & & $\begin{array}{c}\text { Number of officials and } \\
\text { employees surveyed }\end{array}$ & Quantity & $\begin{array}{c}\text { Ratio } \\
\%\end{array}$ & Pass & Fail \\
\hline 1 & Student Button Room & 6 & 1 & 16.7 & & $X$ \\
\hline 2 & Training Department & 8 & 1 & 12.5 & & $X$ \\
\hline 3 & Postgraduate Training Department & 6 & 2 & 33.3 & $X$ & \\
\hline 4 & Continuing Education Department & 16 & 3 & 18.8 & $X$ & \\
\hline 5 & $\begin{array}{l}\text { Department of International Cooperation } \\
\text { and Business }\end{array}$ & 2 & 1 & 50.0 & & $X$ \\
\hline 6 & Financial Planning Division & 11 & 0 & 0.0 & & $X$ \\
\hline 7 & $\begin{array}{l}\text { Department of Examination and } \\
\text { Education Quality Assurance }\end{array}$ & 9 & 2 & 22.2 & & $x$ \\
\hline 8 & Scientific management room & 11 & 4 & 36.4 & $X$ & \\
\hline 9 & Department of Inspection - Legal & 6 & 3 & 50.0 & $\mathrm{X}$ & \\
\hline 10 & Equipment Room & 13 & 4 & 30.8 & $X$ & \\
\hline 11 & Organization and Cadres Room & 9 & 0 & 0.0 & & $X$ \\
\hline 12 & Office & 8 & 3 & 37.5 & $X$ & \\
\hline 13 & Clinics & 3 & 1 & 33.3 & & $X$ \\
\hline 14 & $\begin{array}{l}\text { Project and Infrastructure Management } \\
\text { Board }\end{array}$ & 14 & 10 & 71.4 & $x$ & \\
\hline 15 & Dormitory & 11 & 8 & 72.7 & $X$ & \\
\hline 16 & Information Technology Center & 11 & 6 & 54.5 & $X$ & \\
\hline 17 & International Training Center & 1 & 0 & 0.0 & & $X$ \\
\hline 18 & Student Support Center & 2 & 0 & 0.0 & & $X$ \\
\hline 19 & Learning Resource Center & 11 & 2 & 18.2 & & $x$ \\
\hline 20 & $\begin{array}{l}\text { Center for Training and Testing of Foreign } \\
\text { Languages }\end{array}$ & 8 & 3 & 37.5 & $X$ & \\
\hline 21 & Saigon Practical High School & 21 & 10 & 47.6 & $X$ & \\
\hline 22 & $\begin{array}{l}\text { Saigon University Practical Primary } \\
\text { School }\end{array}$ & 3 & 0 & 0.0 & & $x$ \\
\hline 23 & $\begin{array}{l}\text { Institute of Environmental Technology - } \\
\text { Energy }\end{array}$ & 1 & 1 & 100.0 & & $x$ \\
\hline 24 & $\begin{array}{l}\text { Institute of Data Science - Artificial } \\
\text { Intelligence }\end{array}$ & 1 & 0 & 0.0 & & $x$ \\
\hline 25 & Faculty Of Information Technology & 9 & 3 & 33.3 & $X$ & \\
\hline 26 & $\begin{array}{l}\text { Faculty Of Electronics and } \\
\text { Telecommunication Engineering }\end{array}$ & 4 & 2 & 50.0 & $X$ & \\
\hline 27 & Faculty of Education & 8 & 3 & 37.5 & $X$ & \\
\hline 28 & Faculty of Political Education & 3 & 1 & 33.3 & & $X$ \\
\hline 29 & Kindergarten Pedagogy & 3 & 2 & 66.7 & $x$ & \\
\hline
\end{tabular}




\begin{tabular}{|c|c|c|c|c|c|c|}
\hline 30 & $\begin{array}{l}\text { Faculty of Defense Education - Security } \\
\text { and Physical Education }\end{array}$ & 18 & 7 & 38.9 & $x$ & \\
\hline 31 & Elementary Pedagogy & 12 & 2 & 16.7 & & $\mathrm{X}$ \\
\hline 32 & Environmental Science & 9 & 1 & 11.1 & & $\mathrm{X}$ \\
\hline 33 & Faculty of Law & 4 & 2 & 50.0 & $X$ & \\
\hline 34 & Faculty of Arts & 6 & 2 & 33.3 & $X$ & \\
\hline 35 & Foreign Language departments & 12 & 1 & 8.3 & & $\mathrm{X}$ \\
\hline 36 & Faculty of International Relations & 8 & 1 & 12.5 & & $x$ \\
\hline 37 & Business Administration & 14 & 5 & 35.7 & $X$ & \\
\hline 38 & Faculty of Natural Sciences Pedagogy & 24 & 5 & 20.8 & $X$ & \\
\hline 39 & Faculty of Social Sciences Pedagogy & 15 & 3 & 20.0 & $X$ & \\
\hline 40 & Finance and Accounting department & 2 & 1 & 50.0 & & $x$ \\
\hline 41 & Library and office department & 8 & 1 & 12.5 & & $x$ \\
\hline 42 & Faculty of Mathematics and Applications & 10 & 2 & 10.0 & & $\mathrm{X}$ \\
\hline \multicolumn{2}{|c|}{ Total } & 361 & 109 & 29.9 & 21 & 21 \\
\hline
\end{tabular}

The data in Table 2.1 shows that Saigon University has 361 staff members participating in the survey; in which there are officials and employees who participate in regular table tennis practice with 109 people, accounting for 30.19\%.

The data in Table 2.1 shows that Saigon University has 42 units participating in the survey; there are 21 standard units of table tennis, accounting for $50.0 \%$; Of the 21 units that meet the standards of table tennis, there are 06 units with 6 officials and employees, accounting for $14.28 \%$ and 15 units with 7 officials and employees, or more employees account for $35.72 \%$. The percentage of the number of table tennis units at Saigon University is presented in Chart 2.1.

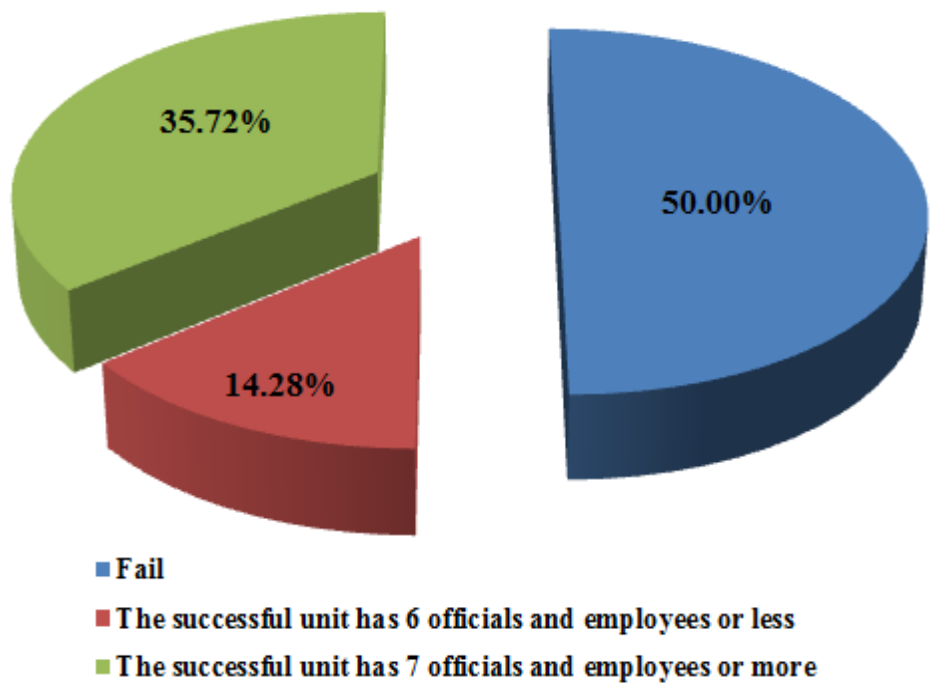

Chart 2.1: The percentage of the number of table tennis units at Saigon University

To evaluate criterion No. 3, the topic analyzed the composition of Physical Education lecturers participating in organizing training activities and playing table tennis at Saigon University, obtained the results in the Table 2.2. 
Table 2.2: Analysis of composition of the teaching staff of physical education participating in the organization of table tennis practice and competition activities at Saigon University

\begin{tabular}{|c|c|c|c|c|}
\hline Ordinal & Survey content & & Quantity & Ratio \% \\
\hline \multirow{3}{*}{1} & \multirow{3}{*}{ Sex } & Male & 0 & 0.0 \\
\hline & & Female & 3 & 100.0 \\
\hline & & Total & 3 & 100.0 \\
\hline \multirow{5}{*}{2} & \multirow{5}{*}{ Ages } & Under 30 years old & 0 & 0.0 \\
\hline & & From 30 years old to 40 years old & 3 & 100.0 \\
\hline & & From 41 years old to 50 years old & 0 & 0.0 \\
\hline & & Over 50 years old & 0 & 0.0 \\
\hline & & Total & 3 & 100.0 \\
\hline \multirow{4}{*}{3} & \multirow{4}{*}{ Academic level } & College & 0 & 0.0 \\
\hline & & University & 0 & 0.0 \\
\hline & & Postgraduate & 3 & 100.0 \\
\hline & & Total & 3 & 100.0 \\
\hline \multirow{6}{*}{4} & \multirow{6}{*}{ Teaching seniority } & Under 5 years & 0 & 0.0 \\
\hline & & From 6 to 10 years & 0 & 0.0 \\
\hline & & From 11 to 15 years & 2 & 66.67 \\
\hline & & From 16 to 20 years & 1 & 33.33 \\
\hline & & Over 20 years & 0 & 0.0 \\
\hline & & Total & 3 & 100.0 \\
\hline
\end{tabular}

The data in Table 2.2 shows that there are 3 teachers and coaches who organize training and table tennis competitions for staff, workers at Saigon University are all female, from 30 to 40 years old, qualified post-graduate education and working experience from 10 to 20 years.

Saigon University has 19 officials and employees of Faculty of Defense Education - Security and Physical Education, so the percentage of the total number of table tennis coaches, table tennis collaborators compared to the total number of coaches and sports collaborators in the school is $15.79 \%$.

To evaluate criterion 4 , criterion 5 , and criterion 6 topics to conduct a survey of teachers and coaches participating in the organization of table tennis training and competition activities at Saigon University showed that:

Criterion 4: Number of clubs, groups, and teams of table tennis.

- Saigon University has 4 table tennis teams: 2 teams with instructors practice in the afternoon and evening, 2 teams without instructors practice in the free time of officials and employees.

- Saigon University has 3 table tennis clubs: 1 club at Saigon University with instructors to practice in the evening, 1 club in the dormitory and 1 club at Saigon Practical High School of Saigon University does not have an instructor to practice in the evenings.

- Saigon University has 2 table tennis teams (male and female) that regularly practice to participate in competitions in the education and training system. 
Criterion 5: Table tennis training and competition facilities.

- Saigon University has a Table Tennis gym at the main campus with 3 tables, 2 practice areas in the dormitory with 2 tables and Saigon Practical High School with 1 table tennis table.

- About equipment, racquet equipment equipped by the practitioner, 200 balls, 6 nets.

Criterion 6: Number of table tennis tournaments held annually at the school.

- Every year, Saigon University organizes 02 table tennis tournaments to celebrate Vietnamese Teachers' Day and celebrate Vietnam Sports Day with about 50 officials and employees participating each turn.

- The school table tennis team participates in the annually table tennis tournament organized by the City Labor Union. Ho Chi Minh City organizes for officials and employees in the education industry.

- The results of the school table tennis team in 2019 and 2020 are as follows:

The Sports Workshop Block of Universities, Colleges, Education and Training Units in 2019: 3rd place in women's team, 2nd place in Women's Doubles, 3rd place in Men's Doubles and 2nd place in Men's Singles over 45 years old.

The Sports Workshop Block of Universities, Colleges, Education and Training Units in 2020: The draw was completed on the competition tree but then canceled due to the Covid-19 epidemic.

\subsection{Actual situation of organization of table tennis practice and competition among officials and employees at Saigon University}

The exam conducted a survey of 109 officials and employees participating in the exercise and 03 teachers and coaches teaching and training table tennis at Saigon University, and obtained the results in Tables 2.3 and 2.4.

Table 2.3: Actual situation of table tennis practice of officials and employees at Saigon University $(n=108)$

\begin{tabular}{|c|c|c|c|c|}
\hline Ordinal & Survey content & & Quantity & Ratio \% \\
\hline \multirow{5}{*}{1} & \multirow{5}{*}{ Form of training } & Team & 10 & 9.2 \\
\hline & & Group, class & 55 & 50.5 \\
\hline & & Club & 12 & 11.0 \\
\hline & & Self-study exercise & 32 & 29.4 \\
\hline & & Total & 109 & 100.0 \\
\hline \multirow{4}{*}{2} & \multirow{4}{*}{ Method of organizing training } & Instructor & 14 & 12.8 \\
\hline & & Without an instructor & 69 & 63.3 \\
\hline & & Both & 26 & 23.9 \\
\hline & & Total & 109 & 100.0 \\
\hline \multirow{5}{*}{3} & \multirow{5}{*}{ Training time } & Under 30 minutes & 2 & 1.8 \\
\hline & & From 30 minutes to 1 hour & 29 & 26.6 \\
\hline & & From 1 hour to 2 hours & 76 & 69.7 \\
\hline & & Over 2 hours & 2 & 1.8 \\
\hline & & Total & 109 & 100.0 \\
\hline
\end{tabular}




\begin{tabular}{|c|c|c|c|c|}
\hline \multirow{5}{*}{4} & \multirow{5}{*}{ Number of training sessions per week } & 01 session & 8 & 7.3 \\
\hline & & 02 sessions & 25 & 22.9 \\
\hline & & 03 sessions & 40 & 36.7 \\
\hline & & Over 3 sessions & 36 & 33.0 \\
\hline & & Total & 109 & 100.0 \\
\hline \multirow{5}{*}{5} & \multirow{5}{*}{ Time to practice } & Morning & 0 & 0.0 \\
\hline & & Afternoon & 22 & 20.2 \\
\hline & & Aafternoon after work & 28 & 25.7 \\
\hline & & Free time & 59 & 54.1 \\
\hline & & Total & 109 & 100.0 \\
\hline \multirow{4}{*}{6} & \multirow{4}{*}{ Training location } & At school & 76 & 69.7 \\
\hline & & Outside of school & 9 & 8.3 \\
\hline & & Both & 24 & 22.0 \\
\hline & & Total & 109 & 100.0 \\
\hline \multirow{4}{*}{7} & \multirow{4}{*}{ Training Costs } & The school pays $100 \%$ & 79 & 72.5 \\
\hline & & Personal spend $100 \%$ & 27 & 24.8 \\
\hline & & The school supports 1 part & 3 & 2.8 \\
\hline & & Total & 109 & 100.0 \\
\hline
\end{tabular}

The data in Table 2.3 shows that:

- Form of exercise: Actual situation of staff officials, group workers, class accounted for the highest rate of $50.5 \%$ and the lowest percentage was for the team, accounting for $9.2 \%$, followed by the club training which accounts for $11 \%$ and self-study. exercise accounts for $29.4 \%$.

- Training organization method: The reality of officials and employees practicing without an instructor is the highest $63.3 \%$ and the lowest is with an instructor $12.8 \%$, officials and employees' practice. according to both accounts for $23.9 \%$.

- Training time: The reality of officials and employees who practice from 1 to 2 hours accounted for the highest rate of $69.7 \%$ and the lowest rate of training under 30 minutes and over 2 hours was 1.8\%, including cadres, officials and employees practice for from 30 minutes to 1 hour, accounting for $26.6 \%$. The percentage of time spent doing abdominal exercise of the staff and employees of Saigon University is presented in Chart 2.2. 


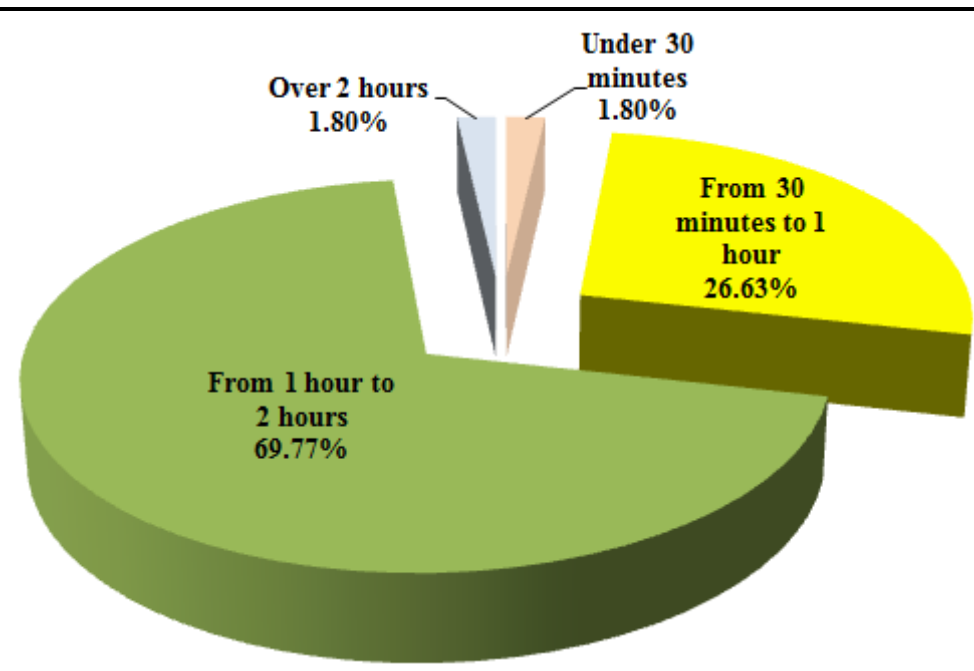

Chart 2.2: The percentage of time spent doing abdominal exercise of the staff and employees of Saigon University

- Number of training sessions per week: actual situation of officials and employees practicing the most is 3 sessions, accounting for $36.7 \%$ and the lowest was 1 session accounted for $7.3 \%$, followed by 2 sessions accounted for $22.9 \%$ and over 3 sessions accounted for $33.0 \%$.

- Time to practice: actual situation of officials and employees practicing the most in their free time accounted for $54.1 \%$ and the lowest is $0.0 \%$ in the morning; followed by $20.2 \%$ in the afternoon and $25.7 \%$ in the afternoon after work.

- Training location: actual situation of officials and employees, worker practice the most at school accounted for $69.7 \%$ and the lowest is outside school, accounted for $8.3 \%$, practice both $24.0 \%$.

- Expenses for training: actual status of staff, the school's staff and employees trained for the most part by only $100 \%$, accounting for $72.5 \%$, and the lowest part of $2.8 \%$ by the University; followed by individuals spending $24.8 \%$. Percentage of expenditure on table tennis practice of Saigon University's officials and employees is presented in chart 2.3.

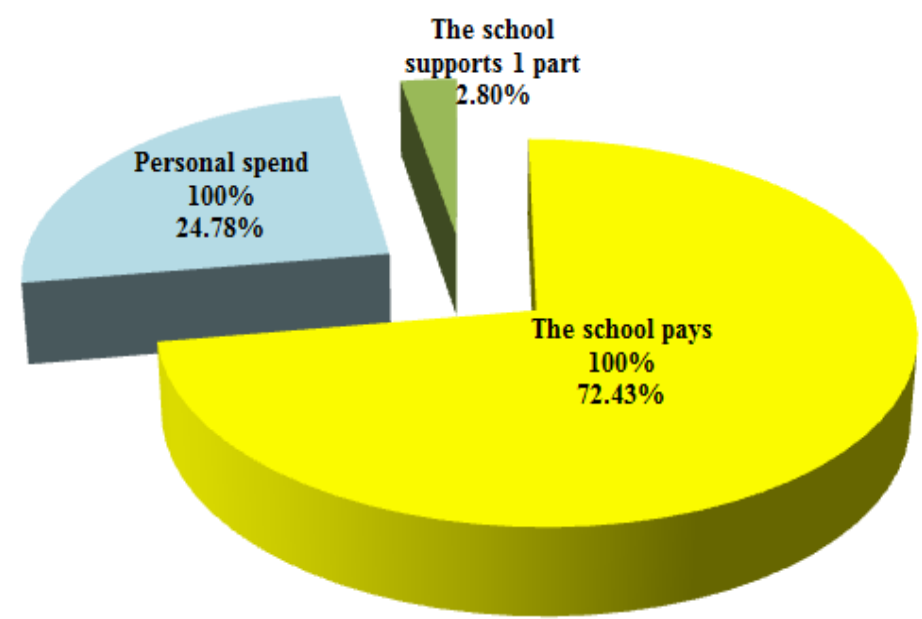

Chart 2.3: Percentage of expenditure on table tennis practice of Saigon University's officials and employees 
Through the above analysis, it shows that the reality of table tennis training of officials and employees at Saigon University. Most of the training sessions in Sai Gon group, class and self-practice $(79.9 \%)$, no instructor (63.3\%), training for 30 minutes - 2 hours $(96.3 \%)$, training for 3 or more sessions $(69.7 \%)$, practice at school $(69.7 \%)$, practice in the afternoon after work and anytime free $(79.8 \%)$.

Table 2.4: Current status of teaching and training methods of table tennis by teachers and coaches at Saigon University $(n=3)$

\begin{tabular}{|c|c|c|c|c|}
\hline Ordinal & Survey content & & Quantity & Ratio \% \\
\hline \multirow{5}{*}{1} & \multirow{5}{*}{ Form of teaching and training } & Team & 1 & 33.3 \\
\hline & & Group, class & 1 & 33.3 \\
\hline & & Club & 1 & 33.3 \\
\hline & & Attached separately & 0 & 0.0 \\
\hline & & Total & 3 & 100.0 \\
\hline \multirow{5}{*}{2} & \multirow{5}{*}{ Teaching and training time } & Under 30 minutes & 0 & 0.0 \\
\hline & & From 30 minutes to 1 hour & 0 & 0.0 \\
\hline & & From 1 hour to 2 hours & 1 & 33.3 \\
\hline & & Over 2 hours & 2 & 66.7 \\
\hline & & Total & 3 & 100.0 \\
\hline \multirow{5}{*}{3} & \multirow{5}{*}{ Number of teaching and training sessions } & 01 session & 0 & 0.0 \\
\hline & & 02 sessions & 0 & 0.0 \\
\hline & & 03 sessions & 1 & 33.3 \\
\hline & & Over 03 sessions & 2 & 66.7 \\
\hline & & Total & 3 & 100.0 \\
\hline \multirow{4}{*}{4} & \multirow{4}{*}{ Time of teaching and training } & Morning & 0 & 0.0 \\
\hline & & Afternoon & 1 & 33.3 \\
\hline & & Afternoon after work & 2 & 66.7 \\
\hline & & Total & 3 & 100.0 \\
\hline
\end{tabular}

The data in Table 2.4 shows that:

- Form of teaching and training: The current situation of teachers, teaching coaches, coaching table tennis in groups, classes, teams and clubs are the same, one person each accounted for $33.3 \%$.

- Teaching and training time: The current situation of teachers, coaches teaching and coaching table tennis for more than 2 hours accounted for the highest rate of $66.7 \%$ and training from 1 hour to 2 hours accounted for $33.3 \%$.

- Number of teaching and training sessions: Actual situation of teachers, coaches teaching and coaching table tennis over 3 sessions accounted for $66.7 \%$ and 3 sessions accounted for $33.3 \%$.

- Time of teaching and training: Current situation of teachers, coaches teaching and training table tennis in the afternoon accounted for $33.3 \%$ and in the afternoon after work accounted for $66.7 \%$.

Through the above analysis, it shows that the current situation of teachers, teaching coaches and training table tennis in groups, classes, teams and clubs are the same (33.3\%), over 2 hours, over 3 sessions and in the afternoon after work (66.7 \%). 


\section{Conclusion}

The results of the study give the following conclusions:

Criteria have been selected: the current situation of the table tennis movement among officials and employees at Saigon University are:

- Criterion 1: Number of officials and employees who regularly practice table tennis.

- Criterion 2: Number of table tennis units.

- Criterion 3: Number of table tennis coaches and collaborators.

- Criterion 4: Number of clubs, groups, and teams of table tennis.

- Criterion 5: Table tennis training and competition facilities.

- Criterion 6: Number of table tennis tournaments held annually at the school. The Evaluation results show that the current situation of physical training and sports movement among officials and employees at Saigon University who participate in regular table tennis practice is 109 people, accounting for $30.19 \%$; 21 standard ping pong units accounted for $50.0 \%$; there are 3 teachers, coaches accounting for $15.79 \%$ of the total number of coaches and sports collaborators in the University; there are 4 teams, 3 clubs and 2 table tennis teams (men and women); there are 1 gymnasium, 2 table tennis practice areas with 6 ping pong tables, 200 balls and 6 nets. Every year, the school organizes 2 table tennis tournaments with about 50 staff and employees participating in each turn.

The actual situation of table tennis training of officials and employees at Saigon University is mostly in group, classes and self-practice $(79.9 \%)$, without an instructor (63.3\%), training for 30 minutes - 2 hours (96.3\%), training for 3 or more sessions $(69.7 \%)$, practicing at school $(69.7 \%)$, practicing in the afternoon after work and at any free time (79.8\%). The actual situation of teachers and teaching coaches and coaching table tennis in groups, classes, teams, and clubs are the same $(33.3 \%)$, practicing for more than 2 hours, over 3 sessions and in the afternoon after work $(66.7 \%)$.

\section{Conflict of Interest Statement}

The authors declare no conflicts of interests.

\section{About the Author}

Nguyen Thi Hoang Anh a lecturer of Faculty of National Defense Education and Physical Education. She held an M.A degree in Education majoring in Physical Education. Her research interests are mainly about the issues related to teaching and learning physical education.

\section{References}

Law on Physical Training and Sports, 2018 has amended and supplemented Clause 2, Article 12. 
Circular No. 02/2009/TT-BVHTTDL, dated March 17, 2009 of the Ministry of Culture, Sports and Tourism, guiding the organization and assessment of mass physical training and sports movements.

Circular No. 08/2012/TT-BVHTTDL, dated September 10, 2012 of the Minister of Culture, Sports and Tourism, regulating the content of assessment of development of physical training and sports.

Circular No: 01/2019/TT-BVHTTDL, dated January 17, 2019 of the Ministry of Culture, Sports and Tourism, on Regulations on assessment of mass physical training and sports movements.

Ho Chi Minh City Department of Culture, Sports and Tourism (2005), Criteria for selection of athletes of key lines, pre-concentration, gifted concentration and recruitment of sports in Ho Chi Minh City, Training Office of Profession School of Ho Chi Minh City Department of Culture, Sports and Tourism.

Nguyen The Truyen, Nguyen Kim Minh, Tran Quoc Tuan (2002), Criteria for evaluation of physical impacts in sport selection and training, Sports Publishing House, Hanoi

邢文华主编（2001）奥运优秀运动员科学选材的研究”下册, 北京体育大学出版社.

邢文华主编（2001）优秀运动员科学选材手册”北京体育大学出版社

Sai Gon University. (2021). Retrieved 16 November 2021, from http://www.sgu.edu.vn. 

be applied to their work. Under the terms of this license, no permission is required from the author(s) or publisher for members of the community to copy, distribute, transmit or adapt the article content, providing a proper, prominent and unambiguous attribution to the authors in a manner that makes clear that the materials are being reused under permission of a Creative Commons License. Views, opinions and conclusions expressed in this research article are views, opinions and conclusions of the author(s). Open Access Publishing Group and European Journal of Physical Education and Sport Science shall not be responsible or answerable for any loss, damage or liability caused in relation to/arising out of conflict of interests, copyright violations and inappropriate or inaccurate use of any kind content related or integrated on the research work. All the published works are meeting the Open Access Publishing requirements and can be freely accessed, shared, modified, distributed and used in educational, commercial and non-commercial purposes under a Creative Commons attribution 4.0 International License (CC BY 4.0). 